\title{
Un nuevo camino
}

\author{
Juan Francisco Pulido Pulido, Patricia Arribas Cobo, Francisca Pulido Agüero, Fernando González García \\ Junta Directiva SEDEN
}

\section{Queridos compañeros}

Ya de lleno metidos en ésta nueva andadura, queremos de nuevo desde aquí transmitir nuestra ilusión ante todo aquello que vislumbramos en el horizonte más cercano.

Somos conscientes en gran parte de las dificultades que aparecen cuando se intenta poner en marcha cualquier proyecto, y que muchas de éstas son ajenas a nuestras decisiones. En estas circunstancias, nuestro compromiso y sentido de la responsabilidad emergen más a flor de piel, a pesar de vivir momentos complicados.

Ser capaces de adaptarnos a los nuevos tiempos y a sus exigencias va a ser un camino complejo. Intentaremos convertir éstas dificultades en proyectos ilusionantes. Es el momento de reinventar cómo ser capaces de aprender juntos. La empatía que se desarrolla entre los miembros de nuestra Sociedad, la puesta en común de nuestras inquietudes y el apoyo de todos y cada uno de nuestros socios, convierten en oportunidad todos los posibles escollos.

Resulta fascinante conocer a tantos compañeros y ser capaces de reconocer el inmenso alcance que nuestra sociedad abarca en los diferentes ámbitos de cuidados que es capaz de abordar. Todo ello aderezado con excelencia, evidencia científica y el tradicional cariño que tuvimos la suerte de aprender de nuestras inolvidables maestras.

Gracias a todos por vuestra capacidad de adaptación, por vuestro trabajo diario por ser los adalides y la referencia de las personas que sufren y por vuestras continuas muestras de apoyo.
Con la base de nuestro objetivo de ampliación de nuestra oferta formativa, estamos de lleno volcados en las áreas de mejora que sean capaces de cubrir las necesidades de todos nuestros socios; porque una buena oferta formativa redunda en una mejor capacitación de la enfermería nefrológica y, por ende, en mejores cuidados que se proporcionan a nuestros pacientes.

Queremos informaros desde aquí, que la organización del Congreso de la Coruña ya está en marcha. La implicación del Comité local, el trabajo de nuestros administrativos, la inestimable aportación de nuestros vocales y nuestro granito de arena, han de mezclarse para conseguir otro Congreso inolvidable, en el que todos nosotros tengamos cabida con nuestros trabajos, conocimiento y experiencia. No olvidamos la enorme importancia que el Congreso Nacional tiene para nuestra Sociedad. Consideramos imprescindible su celebración anual.

La belleza de la ciudad de La Coruña acompañará sin duda a la grandeza que tal evento merece.

No nos queda más que recordar que estamos aquí por y para vosotros y, por tanto, estamos a vuestra disposición para todo aquello que necesitéis y por supuesto, para lo que queráis aportar.

Juntos siempre hemos sido mejores.

Este artículo se distribuye bajo una Licencia Creative Commons Atribución-NoComercial 4.0 Internacional. https://creativecommons.org/licenses/by-nc/4.0/

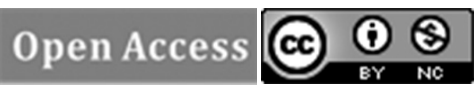

